\title{
Introduction to Special Issue: The Politics of Musical Knowledge in the Soviet Union and Beyond (1930s-1980s) ${ }^{1}$
}

\section{OLGA PANTELEEVA AND DANIIL ZAVLUNOV}

In the conversation about how to best move on from the exclusionary musicological canon, Marina Frolova-Walker's “An Inclusive History for a Divided World?” and Alejandro Madrid's "Diversity, Tokenism, Non-Canonical Musics, and the Crisis of the Humanities in US Academia" fall on the opposite sides of the spectrum. We could label their approaches assimilationist and abolitionist, respectively. Whereas Frolova-Walker maintains that those repertories (Soviet music, in this case) that have been unfairly left out from the master narrative of Western European music should be included in textbooks and histories as a part of the same research frameworks that animate research on Western modernisms, Madrid argues that exclusion is the canon's raison d'être and that including marginalized repertories (Ibero-American music, in this case) would go against its purpose. The solution, according to him, is to reduce the disciplinary space disproportionately occupied by the Anglo-American version of the classical canon, thus freeing up space to study the other $99 \%$ of music on its own terms. ${ }^{2}$

Our project resides in that $99 \%$. Even though the music mentioned on the pages of this issue predominantly belongs to the same Western European repertory (this was, after all, the repertory that concerned Soviet music scholarship), our point is that the shape of that canon was different in the Soviet Union. As Pauline Fairclough and Marina Raku have shown, the Soviet version of the canon was constructed by musicologists during the 1930s in an effort to claim the Western European classics for domestic consumption-by inventing new revolutionary meanings to interpret the classics. ${ }^{3}$ Some works lent themselves to such appropriation more easily than others. For example, by choosing Chopin's Fantaisie in F minor for his analytical magnum opus (1937), Soviet theorist Leo Mazel was contributing to the emerging status of Chopin as a revolutionary in Soviet musical mythology. ${ }^{4}$ That Chopin's mazurkas were apocryphally described by Schumann as "cannons concealed amid blossoms"

\footnotetext{
${ }^{1}$ This special issue began its life as a series of papers read at the Joint Session, "The Politics of Soviet Musicology and Music Theory," of the American Musicological Society and Society for Music Theory (San Antonio, TX, 2018). Although the original panel featured two responses, we decided to forego these for the present publication. However, we are most grateful to Professors Marina Frolova-Walker and Gordon McQuere for their stimulating ideas, many of which found their way into the reworked texts. We are grateful to all the participants in that panel for their invaluable contributions to this project. This issue features most of the original talks, which have been revised and expanded into fully-fledged articles. Individually and collectively, the authors also would like to take this opportunity to thank the reviewers of this journal for their incisive comments on the essays.

${ }^{2}$ Marina Frolova-Walker, “An Inclusive History for a Divided World?” Fournal of the Royal Musical Association 143, no. 1 (2018): 1-20, https://doi.org/10.1080/02690403.2018.1434308; Alejandro L. Madrid, "Diversity, Tokenism, Non-Canonical Musics, and the Crisis of the Humanities in US Academia," Fournal of Music History Pedagogy 7, no. 2 (2017): 124-9.

${ }^{3}$ Pauline Fairclough, Classics for the Masses: Shaping Soviet Musical Identity under Lenin and Stalin (New Haven, CT: Yale University Press, 2016), https://doi.org/10.12987/yale/9780300217193.001.0001, see in particular Chapter 3; Marina Raku, Muzïkal'naya klassika v mifotvorchestve sovetskoy epokhi [Musical classics in the myth-making of the Soviet epoch] (Moscow: Novoye literaturnoye obozreniye, 2014).

${ }^{4}$ See Daniil Zavlunov's article in this issue for a discussion of Mazel's work.
} 
would eventually become widely known in the Soviet Union via its inculcation in music students by way of elementary school music textbooks. This reimagined repertory, together with newly interpreted Russian classics, Soviet compositions, and whatever else that managed to seep through the Iron Curtain, resulted in a configuration that, from the vantage point of the Anglo-American master narrative-both during the Cold War and now_appears distorted and woefully limited by a political intervention. For those who grew up with it, however, it was firmly canonic.

The fields of music theory and music history, as they are practiced in English, have been reckoning with their own political limitations: obdurate Eurocentrism and white racial frame. ${ }^{5}$ One avenue for systemic change-however slow and onerous-has been to provincialize sedimented disciplinary canons, both in repertory and methodological approaches. ${ }^{6}$ Our issue offers a window on the academic environment of the Soviet Union, which for the duration of the Cold War-and arguably longeroccupied the place of the ultimate Other of North American musicology. Now, with the end of the bipolar world, the former Second World has taken its place among the many other Others of the geopolitical West. Therefore, examining the mechanisms of othering particular to the Cold War frame is a part of a much larger academic project, spearheaded by decolonial studies and critical race theory. In this issue, perceiving the music theory and history practiced in Russian as different but equally viable, we highlight the geopolitical and historical contingency of any canon and disciplinary formation.

The "politics" in the title of the issue is broadly defined. The term refers not only to what has traditionally been understood by politics in Soviet music studies-issues of state power and control that still shape most scholarship on Soviet music culture-but also the epistemological politics of music scholarship itself. In the Soviet context, this means the same thing as it did (and does) in Anglophone scholarship: the epistemological appeal of ideologies, disagreements over the meaning of objectivity and social responsibility, and covert political allegiances. Furthermore, the authors in this issue sometimes use the defamiliarizing difference of Soviet music theory and history as a foil to highlight ideological biases of their disciplinary Anglophone counterparts, both in the past and in the present. Many themes explored in this cluster will also resonate with scholars who have no specific interest in musicology or Soviet culture, but who focus on the Cold War and, more generally, on the politics of knowledge production. This inclusive understanding of politics is one of the reasons why this project is appearing on the pages of Music E Politics.

\section{$\star \star \star$}

Methodological precepts of music scholarship in the Soviet Union changed many times over the course of the seven decades of its existence. The rhetoric in the humanities turned like a weather vane according to the ideological winds. However, once adapted to these constraints, Soviet scholars created novel methods and approaches, often fruitfully applying ideals of socially engaged scholarship to the study of music, in dialogue with and antagonistic to the Western strands of music history and theory. The many ways in which ideology both inspired and warped topics and methods of music scholarship

\footnotetext{
${ }^{5}$ Philip Ewell, “Confronting Racism and Sexism in American Music Theory,” Music Theory's White Racial Frame, https://musictheoryswhiteracialframe.wordpress.com/ (accessed June 8, 2020); idem, "Music Theory and the White Racial Frame," Music Theory Online 26, no. 2 (2020), https://mtosmt.org/issues/mto.20.26.2/mto.20.26.2.ewell.html.

${ }^{6}$ The term comes from Dipesh Chakrabarty, Provincializing Europe: Postcolonial Thought and Historical Difference (Princeton, NJ: Princeton University Press, 2000).
} 
during the Soviet period make up one of the core themes of this special issue. Starting with the tightening of ideological control during the Cultural Revolution circa 1930 and continuing through the late "stagnation" period of the Soviet state, the essays trace the politics of producing and sharing knowledge about music in the Soviet Union.

Some authors featured in the issue are music historians and others are theorists; however, the articles blend disciplinary concerns and approaches in order to make the issue relevant to scholars from both fields. The problems that each article explores are not very different from each other, even if the topics are. All authors are tackling the same set of questions, with one in particular: what forcesdisciplinary, ideological, and cultural-shaped the production of knowledge in the Soviet Union? Without simultaneously thinking about music history, theory, music pedagogy, cultural policy, and international traffic of ideas, we can never see the full picture of Soviet "musical science."

It is precisely in their emphasis on musical knowledge (and more generally on intellectual thought about music) that the essays in this issue differ from other significant recent examinations of music in the Soviet period. One of the great accomplishments of that revisionist scholarship has been the everbroadening definition of "music" - one that allows for more encompassing, and also more accurate, historiography. The term now embraces composers and their works; performance and performers; massive bureaucratic machines (composer unions, state awards mechanisms, performance competitions, etc.) that enable creative activity; larger cultural institutions (theaters, troupes, orchestras, etc.); and musical life as experienced by audiences. ${ }^{7}$ Largely missing from this expanding definition are people and institutions responsible for defining, producing, and propagating musical knowledge-music historians and theorists, bureaucrats and functionaries, primary school music teachers and graduate students: in other words, the music academe. It is their day-to-day work, worldviews, motivations, professional aspirations, interpersonal relationships, and professional networks that have largely escaped scholarly notice. Without further attention to the agencies of scholarship, instruction, and administration, it is impossible to tell the story of music in the Soviet Union in all of its multifaceted complexity.

Over the past four decades, many studies have furnished Western scholarship with important introductions to Russian and Soviet music-theoretical thought, broadening the largely Eurocentric field of history of music scholarship. One of the earliest English-language attempts to tackle Russian and Soviet music theory remains one of the most influential. As part of her pioneering critical examination of the discipline, Ellon Carpenter scrutinized how Marxism redefined music theory in the first decades

\footnotetext{
${ }^{7}$ For some important recent studies, see: Kiril Tomoff, Creative Union: The Professional Organization of Soviet Composers, 1939-1953 (Ithaca, NY: Cornell University Press, 2001); Simo Mikkonen, Music and Power in the Soviet 1930s: A History of Composers' Bureaucracy (Lewiston, NY: Mellen, 2009); Kiril Tomoff, Virtuosi Abroad: Soviet Music and Imperial Competition during the Early Cold War, 1945-1958 (Ithaca, NY: Cornell University Press, 2015), https://doi.org/10.7591/cornell/9780801453120.001.0001; William J. Risch, ed., Youth and Rock in the Soviet Bloc: Youth Cultures, Music, and the State in Russia and Eastern Europe (Lanham, MD: Lexington Books, 2015); Pauline Fairclough, Classics for the Masses: Shaping Soviet Musical Identity Under Lenin and Stalin (New Haven, CT: Yale University Press, 2016); Marina Frolova-Walker, Stalin's Music Prize: Soviet Culture and Politics (New Haven, CT: Yale University Press, 2016), https://doi.org/10.12987/yale/9780300208849.001.0001; Simon Morrison, Bolshoi Confidential: Secrets of the Russian Ballet from the Rule of the Tsars to Today (New York: W. W. Norton, 2016); Anne Searcy, “The Recomposition of Aram Khachaturian's Spartacus at the Bolshoi Theater, 1958-1968," The fournal of Musicology 33, no. 3 (Summer 2016): 362-400, https://doi.org/10.1525/jm.2016.33.3.362; Gleb Tsipursky, "Jazz, Power, and Soviet Youth in the Early Cold War, 1948-1953,” The Fournal of Musicology 33, no. 3 (Summer 2016): 332-361, https://doi.org/10.1525/jm.2016.33.3.332; Simo Mikkonen and Pekka Suutari, eds., Music, Art and Diplomacy: East-West Cultural Interactions and the Cold War (London and New York: Routledge, 2016); Simo Mikkonen, Giles Scott-Smith, and Jari Parkkinen, eds., Entangled East and West: Cultural Diplomacy and Artistic Interaction during the Cold War (Berlin and Boston: De Gruyter, 2019), https://doi.org/10.1515/9783110573169.
} 
of the Soviet period. ${ }^{8}$ Hers was one of the first studies that pushed back against the persistent myth of theory's ideological neutrality. Even before she completed her research, in her application for the IREX travel grant in 1976, she asked, "How parallel is the development of Soviet theory to that in our own country? Are Soviet theorists concerned with the same topics in relation to their music as we are, or totally different ones? Does music theory contain an intrinsic integrity or a genetic development that is independent of any ideological position?" ${ }^{9}$ Her questions continue to resonate today.

Unsurprisingly, Carpenter's work nourishes several essays in this issue, including Daniil Zavlunov's "Defining and Defending Music Analysis in the Soviet 1930s." The late 1920s and early 1930s marked a period of intense search for "Marxist theory of music" in Soviet academe. Not only did the new music-theoretical system have to align with the Marxist doctrine, but it also needed to be perceived as essentially Soviet, be scientifically rigorous yet offer viable engagement with music as art. One of the most significant manifestations of the search was the creation of a new analytical method, "tselostnïy analiz" (holistic analysis), which aspired to synergistically integrate considerations of musical structure, content, and context in the study of musical works. ${ }^{10}$ In the process of its development, Leo Mazel, Viktor Zuckerman, and Iosif Rïzhkin tried to position music analysis as an independent branch of musical knowledge, one that could lay claim to scientific objectivity and at the same time meet the needs of dialectical materialism. The merger of the two was made possible by the method's primary concern with uncovering musical content_of teasing out musical works' structural and expressive components as manifestations of social reality. However, Zavlunov's focus is not on holistic analysis per se but on its creators' impulse to define and legitimize the discipline of music analysis as the central preoccupation of musicology. The three originators were so successful in their project that by the end of the 1930s music analysis was accepted —even by its detractors-as the most significant and unique achievement of Soviet music scholarship (and, as Matthew Honegger's essay shows, one that could be marketed even to the West). And although the fortunes of holistic analysis oscillated greatly in the turbulent 1940s and 1950s, the holistic method has continued to influence both historical and theoretical scholarship in Russia to the present.

As it offers a composite account of music analysis as a discipline in a different time and place, Zavlunov's article simultaneously furnishes a foil against which one could reflect on the travails of Anglophone musicology. At the core of the 1930s polemics surrounding "holistic analysis" traced by Zavlunov were, in fact, existential questions that transcend their immediate contexts: what does it mean to know music? Who gets to define the scholarly instruments used to create that knowledge? Who gets to wield these instruments, and to what end? In fact, many of the concerns and aspirations of Soviet music scholars in the 1920s and 1930s parallel and anticipate those of critics and analysts in the Anglophone West in the latter half of the twentieth century. In the case of music analysis, these include analysis for its own sake and for a better hearing of a musical work (e.g., Charles Rosen, David Lewin, Joseph Straus), stylistic analysis (e.g., Leonard B. Meyer), concern with the experience of music (e.g.,

\footnotetext{
${ }^{8}$ Ellon DeGrief Carpenter, “The Theory of Music in Russia and the Soviet Union, ca. 1650-1950” (PhD diss., University of Pennsylvania, 1988).

${ }^{9}$ RC 124, folder 2, Carpenter, Ellon (1976-1977), International Research and Exchanges Board Records, Manuscript Division, Library of Congress, Washington, DC.

${ }^{10}$ This cluster of articles uses the transliteration system developed by Gerald Abraham for the New Grove and modified by Richard Taruskin. See Richard Taruskin, Musorgsky: Eight Essays and an Epilogue (Princeton, NJ: Princeton University Press, 1993), xix-xx. Familiar names appear in their Anglicized form in the main text (e.g., Igor, Yuri, Scriabin) but in a strict transliteration for bibliographic references (e.g., Igor', Yuriy, Skryabin).
} 
Kofi Agawu), topical analysis or analysis as a cipher to music's expressive potential (e.g., Leonard Ratner, Wye J. Allanbrook, Agawu, Robert Hatten), and analysis as performance and composition (e.g., Edward T. Cone, Agawu). Frequently, the writings of early Soviet music historians also foreshadow the ideas (and at times even the rhetoric) of the so-called "New Musicologists," for example, Joseph Kerman's general critique of analysis and his crusade for social relevance of scholarship by way of music criticism. $^{11}$

These convergences, which make possible an infusion of novel theoretical concepts into Anglophone theory, have not gone unnoticed by Western music theorists. Indeed, several scholars have already argued that Russian-Soviet music theory might supply different and superior tools for understanding and engaging with the art music of that region, especially music of the twentieth century (Scriabin, Prokofiev, Shostakovich, Schnittke, Gubaidulina, and others). For instance, Varvara Dernova's conceptualization of Scriabin's harmonic structures has become fundamental for the study of this composer's output in the West. ${ }^{12}$ In a more recent example, Inessa Bazayev and Ellon Carpenter ask, "What new angles does Russian theory offer on Western theoretical concepts? What new concepts can Russian theory introduce to Anglophone scholarship?" Articles in their collection, "Perspectives on Twentieth-Century Russian Theory," offer some fascinating and remarkably diverse answers. ${ }^{13}$

In this issue, Christopher Segall's essay continues this lineage, but develops it further by offering an essentially political argument. In "Yuri Kholopov and Twelve-Toneness," Segall closely reads "Who Invented Twelve-Tone Technique?” (1983), an essay by a preeminent Soviet theorist Yuri Kholopov, who already in the 1980s pluralized the definition of twelve-tone technique, preferring to speak of twelve-tone techniques and their various creators. Explicitly arguing against the Western framing of twelve-tone technique that centers Arnold Schoenberg as its sole creator to the detriment of the rich intellectual environment of the time, and rejecting German hegemony over the concept of twelvetoneness, Kholopov contextualized the development of Schoenberg's dodecaphony among other contemporaneous compositional trends. He demonstrated how numerous composers of the 1910s-20s used serial techniques, referential sonorities, twelve-tone series, and twelve-tone chords. This allowed Kholopov to accommodate and elevate several Russian composers, who only a generation earlier would

\footnotetext{
${ }^{11}$ Joseph Kerman, "How We Got Into Analysis, and How to Get Out," in Write All These Down: Essays on Music (Berkeley: University of California Press, 1994), 12-32 [originally published in Critical Inquiry 7, no. 2 (1980): 311-31. Kerman's concerns, however, date back to the early 1960s. See, for example, idem, "A Profile for American Musicology" [1965], in Write All These Down, 3-11.

${ }^{12}$ Ever since Roy Guenther's English translation of Dernova's Garmoniya Skryabina, virtually every Anglophone study of Scriabin has made reference to Dernova's work. See Roy J. Guenther, "Varvara Dernova's 'Garmoniia Skriabina': A Translation and Critical Commentary” (PhD diss., Catholic University of America, 1979). Dernova's work itself was informed by the theories of Boleslav Yavorsky. References to Yavorsky's ideas are also now commonplace in Anglophone theory, thanks, in no small measure, to the work of Gordon McQuere and Ellon Carpenter. See, for example, Gordon D. McQuere, "The Elements of the Structure of Musical Speech by S. V. Protopopov: A Translation and Commentary" (PhD diss., University of Iowa, 1978); Gordon D. McQuere, ed., Russian Theoretical Thought in Music (Ann Arbor: UMI Research Press, 1983; Reprint edition, Rochester, NY: University of Rochester Press, 2009). Some of the more recent scholarship that both interprets and uses Yavorsky includes Philip A. Ewell, "Rethinking Octatonicism: Views from Stravinsky's Homeland," Music Theory Online 18, no. 4 (2012), https://doi.org/10.30535/mto.18.4.2; idem, "On the Russian Concept of Lād, 18301945," Music Theory Online 25, no. 4 (2019), https://doi.org/10.30535/mto.25.4.4.

${ }^{13}$ Inessa Bazayev and Ellon D. Carpenter, eds., "Introduction: Russian Theoretical Thought Rediscovered and Reevaluated" to special issue, "Perspectives on Twentieth-Century Russian Theory," Music Theory Online 20, no. 3 (2014), https://doi.org/10.30535/mto.20.3.4. The essays include "The Concept of Mutability in Russian Theory" (Ellen Bakulina), "The Expansion of the Concept of Mode in Twentieth-century Russian Music Theory" (Inessa Bazayev), "A Glimpse at Iuriı Kholopov's Garmonicheskiǔ analiz” (Zachary A. Cairns), "The Parameter Complex in the Music of Sofia Gubaidulina [based on theories of Valentina Kholopova]" (Philip A. Ewell), and others.
} 
not have figured in the twelve-tone historical discourse at all (a point also made by Inessa Bazayev's essay). Thus, Kholopov positioned serial dodecaphony as simply one manifestation of a network of compositional concerns shared widely at a particular historical moment. In so doing, he was realigning the balance of power-political and intellectual—both at home and abroad. Most significantly, deconstructing Kholopov's study and reading it against the more recent Anglo-American scholarship on serialism (which post-dates Kholopov), Segall urges his reader to view twelve-tone technique as a cultural and political construction, subject to renegotiation. Finally, he shows that it was Kholopov's reliance on the Soviet configuration of the musical canon-one that afforded Russian and Soviet music truly canonic status - that enabled him to re-envision twelve-toneness.

This approach represents another point of departure from the lingering Cold War frame that tended to regard any admixture of Marxist ideology into academic knowledge as poisonous. For instance, even Ellon Carpenter's insightful critique revealed a degree of discomfort with Marxism. With its focus on ideology, she argued, Marxism not only stalled the development of music theory, but almost laid waste to the discipline as a whole. ${ }^{14}$ This Cold War frame, which positions all humanistic knowledge produced in authoritarian political systems beyond the geopolitical West as flawed-beyond-repair, has been preventing Anglophone musicologists from entering a productive dialogue with this body of scholarship_scholarship that was shaped by different ideologies and political circumstances but was often grappling with the same issues (and often decades sooner). The essays gathered here by-and-large resist such a totalizing view, calling for a more nuanced approach to the complex relationship between political ideology and epistemology. Deliberately teasing out the ideological elements that were feeding various theoretical models in use in the Soviet Union, they make an implicit claim that ideologies, whether they might seem appealing from the vantage point of today, could lead to radical innovation in scholarship.

Which is not to say that they always did. First, ideological justifications of oppression in the Soviet Union are a topic that has been researched extensively in Anglophone Slavic studies. Inessa Bazayev's essay comes from within that tradition, focusing on ideology and censorship. In "The Politics of Atonality during the Thaw and Beyond," she provides a critical survey of attacks on atonal music both foreign and domestic, which began to appear in Soviet academic periodicals around 1930 and persisted into the 1980s. In the 1950s and 1960s, the term "atonality" was used as a weapon to smear the reputation of young Soviet composers who did not follow the official line of socialist-realist art in their works. In the second half of her article, she argues that in the late Soviet period Yuri Kholopov tried to re-validate atonality and, in so doing, contributed mightily to rehabilitating suppressed Russian and Soviet composers and their works. This article, then, intersects with Segall's discussion of Kholopov and his conception of atonality. Both studies deal with the politics of reception of atonality, but in strikingly different ways. Whereas Segall views Kholopov's project as essentially political, Bazayev argues the opposite: Kholopov's writings sought to depoliticize atonality.

Second, that Soviet ideals were worthy ideals, despite the failure to achieve them, is an idea that also gradually takes root in Anglophone studies of Russian and Soviet music. For instance, Richard Taruskin readily admits that some of those ideals have had an impact on his own scholarship, and he wanted to

${ }^{14}$ This is evident throughout Carpenter, “The Theory of Music in Russia and the Soviet Union,” Part VII, but see especially pages $915,983,1028-9,1057,1161-3$. 
practice what Soviet musicologists of the 1930s preached but never could realize. ${ }^{15}$ Thus, to desire socially engaged historiography and socially aware music theory is one thing. To produce scholarship that actually realizes these ideals is another. This is a paradox that plagued Soviet "musical science" and plagues today's Anglophone music scholarship, since the latter's disciplinary and curricular reality rarely lives up to its ostensible commitment to dismantling white supremacy.

If segments of Soviet music theory have experienced a gradual acceptance by and even absorption into Anglophone scholarship, Soviet music history never enjoyed the same respect in the West, being seen on both sides of the Iron Curtain as a less objective field, one more prone to political co-optation. Since the "case of musicologists" in 1949-the lesser known counterpart of the infamous 1948 anti-formalist campaign, when several leading musicologists were chastised for citing foreign scholars and other formalist transgressions-music history in the Soviet Union lost credibility as a discipline (especially when compared to the purportedly less political music theory). ${ }^{16}$ It also was more subject to censorship and selfcensorship than music theory, which led music historians to develop a performative writing style that to the untrained eye could appear as thoroughly politicized. ${ }^{17}$ Despite the fact that several scholars working in these conditions, such as Valentina Konen and Mikhail Druskin, managed to create methodologically sound music-historical scholarship, arguably, the field has yet to recover from being seen in the West as hopelessly isolated and backwards. ${ }^{18}$

Most essays presented here, then, also attempt to dispel the myth that Soviet music scholarship found itself in a hermetic isolation from the developments in Western musicology (broadly defined). The last cluster of articles deals with the complex intellectual and ideological relationships between scholars in Eastern and Western blocs, analyzing the traffic of ideas and people between the Soviet Union, the United States, and the German Democratic Republic. In order to trace these concrete personal and ideological connections, the essays ground their arguments in original archival research and a wealth of other primary sources. Matthew Honegger presents new findings from the archive of the All-Union Society for Cultural Relations with Foreign Countries, preserved in The State Archive of the Russian Federation. In addition to drawing on her research in former East German archives, Anicia Timberlake brings the reader's attention to overlooked pedagogical materials and to philosophical debates that unfolded in professional journals. Finally, Olga Panteleeva brings to the discussion the IREX files at the Library of Congress and documents related to the US-Soviet cultural exchange from the National Archives.

In "Paper Soldiers: Building Soviet-American Musical Ties in a Time of War," Matthew Honegger rectifies an omission in the studies of Cold War musical diplomacy, offering a narrative of continuity.

\footnotetext{
${ }^{15}$ Richard Taruskin, "Found in Translation," Min-Ad: Israel Studies in Musicology Online 16 (2019): 1-31; see especially 11, 29-31, https://www.biu.ac.il/hu/mu/min-ad/2019/Richard_Taruskin_Found-in-Translation.pdf.

${ }^{16}$ Olga Manulkina, “Foreign' versus 'Russian' in Soviet and Post-Soviet Musicology and Music Education,” in Russian Music since 1917: Reappraisal and Rediscovery, ed. Marina Frolova-Walker and Patrick Zuk (Oxford: Oxford University Press, 2017), https://doi.org/10.5871/bacad/9780197266151.003.0010.

${ }^{17}$ Liudmila Kovnatskaya, "Self-censorship during the Cold War and beyond," paper presented at AMS, Louisville, KY, November 12-15, 2015; Olga Panteleeva, “The Wheat and the Chaff: Reading Censored Scholarship," paper presented at ASEEES, Boston, MA, December 6-9, 2018.

${ }^{18}$ See, for instance, Mikhail Druskin, Igor' Stravinsky: Lichnost', Tvorchestvo, Vzglyadï [Igor Stravinsky: his life, works, and views] (Leningrad: Sovetskiy kompozitor, 1974); Valentina Konen, Puti amerikanskoy muzïki: ocherki po istorii muzïkal'noy kul'turi SShA [Paths of American music: studies in the history of musical culture of the United States] (Moscow: Sovetskiy kompozitor, 1961).
} 
Tracing the activity of the All-Union Society for Cultural Relations with Foreign Countries (VOKS) during WWII, the author provides a prehistory to networks that would emerge during the heyday of Cold War cultural diplomacy. Although formal correspondence failed to establish substantive and lasting exchange, the essay contends that more permanent channels of personal contact were held open by VOKS's own staff. The second half of the essay thus focuses on the work of Grigoriy Shneyerson, the secretary of the VOKS music section. A professional cultural diplomat, Shneyerson maintained many epistolary friendships with musicians outside of the Soviet Union, such as Elie Siegmeister. In these correspondences, which sometimes lasted for decades, friendship meshed with the work of political persuasion. Similar importance of personal contacts in surmounting the ideological barriers will re-emerge in Olga Panteleeva's account of North American musicologists visiting the Soviet Union on travel grants in subsequent decades.

In the 1950s, the GDR musicologist Ernst Hermann Meyer was one of the many who took up one of the most influential_and, arguably, the most inscrutable—concepts of Soviet musicology, the notion of intonatsiya (intonation). The appeal of Boris Asafyev's theory, besides its Marxist roots, was its fluidity-the concept could encompass as little or as much as was ideologically needed, its signification mutating easily in the hands of those wielding it as an analytical tool. In "Boris Asafyev's Intonatsiya and German Folk Song in the German Democratic Republic," Anicia Timberlake zeroes in on the distinctive East German version of the concept, arguing against the established notion of Soviet "cultural occupation." Rather, the author points out the fact that the notion of intonatsiya was seamlessly appropriated for German nationalist and educational ends. In the process, the rich centuries-long history of German influence on Russian music theory was now being channeled back in a "family reunion" of sorts-an apt metaphor for the complex power dynamics at hand. After offering an overview of the multiplicity of meanings Asafyev's ambiguous concept took in its East German reincarnation, the author shows that the simplest of theseintonatsiya as a vocabulary of melodic "turns," characteristic of a national style-became the dominant one. That meaning was eventually put into practice in new pedagogical approaches to children's music education. Children's music, by virtue of its "simplicity" and closeness to "nature," was positioned as an extension of German folk music and an expression of German character. Thus the prestige of scientific Marxism was used for the specific goal of reaffirming the value of the German musical tradition in a new political context.

It is not coincidental that Asafyev's theory was central to the theoretical conceptions transmitted to the countries in the Eastern bloc in the late 1940s and early 1950s. At the core of Asafyev's conception (which took its final shape by 1947) is music's communicative potential. His theory furnished one way of accessing musical content. Holistic analysts, discussed in Zavlunov's article, tried to do something similar but by different means. While acknowledging Asafyev's influence and some overlap in ideas, they also distanced themselves from Asafyev, whose theory they found to be too unsystematic. Their way of tackling content approximated what today, in Anglophone scholarship, is called topic theory. Following the "case of musicologists" in 1949-when the three holistic analysts were censured and penalized for being cosmopolitan formalists who kowtowed to the West (to use the official parlance)—and for almost a decade thereafter, their method was not seen as viable in scholarship. It was in this decade that Asafyev's theory of intonation took root and began to wield enormous influence at home and abroad (including, in the latter decades of the century, in the Western musical semiotics).

In the early 1960s, American musicologist Malcolm Hamrick Brown traveled to the Soviet Union to spend an academic year in Moscow. He attended classes at the Moscow Conservatory, worked in libraries, 
and socialized with students at the dorms while playing jazz recordings. Years later, his and other visitors' lived experience in Soviet cities profoundly influenced how American scholars viewed Russian music. In "Music is an A-Political Subject': North American Musicologists in the Soviet Union, 1960s-1970s," Olga Panteleeva details experiences of the US musicologists-Malcolm Hamrick Brown, Laurel Fay, Theodore Levin, and Richard Taruskin, among others-who applied for the travel grant that funded research trips to the Soviet Union. Contrary to what later became a mainstay of the US scholarship on Soviet music - considering music's relationship with the state- the notion of music as essentially apolitical became the key that allowed both the Soviet and American sides to disguise the overtly political aims of the exchange program. The research topics selected for exchange avoided political subject matter altogether. Ellon Carpenter's project mentioned at the outset of this introduction was rejected precisely because it strayed off this path. Once on the ground, American exchangees were to function as "sources of unbiased information" for Soviet citizenry about the "American way of life" - a concept that was raced, gendered, and conformed to strict standards of sexuality, ability, and mental health. At the same time, reports on the students' lives inside Soviet institutions were used by the State Department as valuable reconnaissance work. Still, the young scholars attempted to engage with the Soviet musical life on equal terms and beyond the limitations of their research topics. Results of such prolonged exposure would come to fruition during the 1980s and 1990s, when the former IREX exchange participants moved beyond Cold War platitudes and put forth less othering approaches to Soviet music.

The authors of the essays in this special issue advance and complicate this lineage, attempting to engage with Soviet musical knowledge on its own terms. This was the objective of the project from its outset, when it was conceived in 2017 at an annual meeting of the American Musicological Society after a discussion of the absence of Russian scholars' perspectives in the Anglophone studies of Russian and Soviet music, the systemic discursive, financial, and political obstacles to their participation, and, consequently, the lopsided positionality of knowledge in the field. ${ }^{19}$ The continued absence of Russian scholars from this issue is testimony to the tenacity of those obstacles. Putting a spotlight on the many ways in which personal experiences of our protagonists shaped their academic work means acknowledging that our arguments are also shaped by personal experiences with the damage that the Cold War intellectual frame continues to inflict not only on knowledge production but on actual lives. This positionality affords us a particularly clear view, first, on the shortcomings of the Cold War frame that still holds a powerful sway over Anglophone Soviet music studies, as it does over the North American political discourse at large; and second, on the many parallels and convergences between the experiences of scholars in the former Eastern and Western blocs, all doing political work through their scholarship. Indeed, on a larger scale, it is in this provincializing potential, and in its ability to reflect on the history of its own Otherness, that the deep value and power of the field of Russian music studies resides. By articulating this, we hope yet again to draw attention to the ways in which scholars who study Soviet and Russian music can productively align their work with our colleagues' struggles in other corners of the musicological and music-theoretical communities, working to change the oppressive status quo.

\section{Bibliography}

${ }^{19}$ Panel “Defining Russia Musically Today,” AMS, Rochester, NY, November 9-12, 2017. 
Bazayev, Inessa, and Ellon D. Carpenter, eds. "Introduction: Russian Theoretical Thought Rediscovered and Reevaluated." Music Theory Online 20, no. 3 (2014). https://doi.org/10.30535/mto.20.3.4.

Carpenter, Ellon DeGrief. "The Theory of Music in Russia and the Soviet Union, ca. 1650-1950.” PhD diss., University of Pennsylvania, 1988.

Chakrabarty, Dipesh. Provincializing Europe: Postcolonial Thought and Historical Difference. Princeton, NJ: Princeton University Press, 2000.

Druskin, Mikhail. Igor' Stravinsky: Lichnost', Tvorchestvo, Vzglyadï [Igor Stravinsky: His life, works, and views]. Leningrad: Sovetskiy kompozitor, 1974.

Ewell, Philip A. "Confronting Racism and Sexism in American Music Theory." Music Theory's White Racial Frame. Accessed June 8, 2020. https://musictheoryswhiteracialframe.wordpress.com.

_. "Music Theory and the White Racial Frame." Music Theory Online 26, no. 2 (2020). https://mtosmt.org/issues/mto.20.26.2/mto.20.26.2.ewell.html.

—. "On the Russian Concept of Lād, 1830-1945." Music Theory Online 25, no. 4 (2019). https://doi.org/10.30535/mto.25.4.4.

_. "Rethinking Octatonicism: Views from Stravinsky’s Homeland." Music Theory Online 18, no. 4 (2012). https://doi.org/10.30535/mto.18.4.2.

Fairclough, Pauline. Classics for the Masses: Shaping Soviet Musical Identity under Lenin and Stalin. New Haven, CT: Yale University Press, 2016. https://doi.org/10.12987/yale/9780300217193.001.0001.

Frolova-Walker, Marina. “An Inclusive History for a Divided World?” Journal of the Royal Musical Association 143, no. 1 (2018): 1-20. https://doi.org/10.1080/02690403.2018.1434308.

- Stalin's Music Prize: Soviet Culture and Politics. New Haven, CT: Yale University Press, 2016. https://doi.org/10.12987/yale/9780300208849.001.0001.

Guenther, Roy J. "Varvara Dernova's 'Garmoniia Skriabina': A Translation and Critical Commentary.” PhD diss., Catholic University of America, 1979.

Kerman, Joseph. Write All These Down: Essays on Music. Berkeley: University of California Press, 1994).

Konen, Valentina. Puti amerikanskoy muziki: ocherki po istorii muzikal'noy kul'turï SShA [Paths of American music: Studies in the history of musical culture of the United States]. Moscow: Sovetskiy kompozitor, 1961.

Kovnatskaya, Liudmila. "Self-censorship during the Cold War and beyond." Paper presented at AMS, Louisville, KY, November 12-15, 2015.

Madrid, Alejandro L. "Diversity, Tokenism, Non-Canonical Musics, and the Crisis of the Humanities in US Academia." Journal of Music History Pedagogy 7, no. 2 (2017): 124-9.

Manulkina, Olga. “Foreign' versus 'Russian' in Soviet and Post-Soviet Musicology and Music Education.” In Russian Music since 1917: Reappraisal and Rediscovery, edited by Marina Frolova-Walker and Patrick Zuk. New York: Oxford University Press, 2017. https://doi.org/10.5871/bacad/9780197266151.003.0010.

McQuere, Gordon D. "The Elements of the Structure of Musical Speech by S. V. Protopopov: A Translation and Commentary.” PhD diss., University of Iowa, 1978.

McQuere, Gordon D., ed. Russian Theoretical Thought in Music. Ann Arbor: UMI Research Press, 1983; Reprint edition, Rochester, NY: University of Rochester Press, 2009. 
Mikkonen, Simo. Music and Power in the Soviet 1930s: A History of Composers' Bureaucracy. Lewiston, NY: Mellen, 2009.

Mikkonen, Simo, and Pekka Suutari, eds. Music, Art and Diplomacy: East-West Cultural Interactions and the Cold War. London and New York: Routledge, 2016.

Mikkonen, Simo, Giles Scott-Smith, and Jari Parkkinen, eds. Entangled East and West: Cultural Diplomacy and Artistic Interaction during the Cold War. Berlin and Boston: De Gruyter, 2019. https://doi.org/10.1515/9783110573169.

Morrison, Simon. Bolshoi Confidential: Secrets of the Russian Ballet from the Rule of the Tsars to Today. New York: W. W. Norton, 2016.

Panteleeva, Olga. "The Wheat and the Chaff: Reading Censored Scholarship." Paper presented at ASEEES, Boston, MA, December 6-9, 2018.

Raku, Marina. Muzikal'naya klassika v mifotvorchestve sovetskoy epokhi [Musical classics in the mythmaking of the Soviet epoch]. Moscow: Novoye literaturnoye obozreniye, 2014.

Risch, William Jay, ed. Youth and Rock in the Soviet Bloc: Youth Cultures, Music, and the State in Russia and Eastern Europe. Lanham, MD: Lexington Books, 2015.

Searcy, Anne. "The Recomposition of Aram Khachaturian's Spartacus at the Bolshoi Theater, 1958-1968." The Journal of Musicology 33, no. 3 (Summer 2016): 362-400. https://doi.org/10.1525/jm.2016.33.3.362.

Taruskin, Richard. "Found in Translation.” Min-Ad: Israel Studies in Musicology Online 16 (2019): 1-31. https://www.biu.ac.il/hu/mu/min-ad/2019/Richard Taruskin_Found-in-Translation.pdf.

—. Musorgsky: Eight Essays and an Epilogue. Princeton, NJ: Princeton University Press, 1993.

Tomoff, Kiril. Creative Union: The Professional Organization of Soviet Composers, 1939-1953. Ithaca, NY: Cornell University Press, 2001.

- Virtuosi Abroad: Soviet Music and Imperial Competition during the Early Cold War, 1945-1958. Ithaca, NY: Cornell University Press, 2015. https://doi.org/10.7591/cornell/9780801453120.001.0001.

Tsipursky, Gleb. "Jazz, Power, and Soviet Youth in the Early Cold War, 1948-1953." The Journal of Musicology33, no. 3 (Summer 2016): 332-61. https://doi.org/10.1525/jm.2016.33.3.332. 